\title{
LISTENING GUIDE
}

The audio files can be found at

http://www.manchesteropenhive.com/sonic-ethnography/sound

$$
\begin{gathered}
\text { Accettura } 2005 \text { - Tuesday (17 May) - } \\
\text { by Steven Feld (6:37) }
\end{gathered}
$$

Track 6 from Steven Feld's soundscape composition, published in When the Trees Resound (Scaldaferri and Feld 2019, CD 1). Feld's track, in its extreme temporal compression, in a few dense minutes distils the main sonic elements of the frantic concluding day of the Maggio festival.

$0: 01$. Sounds of ropes tensing during the raising of the tree.

0:50. A zampogna songs (3 palm zampogna played by Alberico Larato, voices of Giuliano Moles and Domenico Fanuele). From the lyrics: 'This zampogna is the colour of gold / the hands of those who play it are more beautiful'.

2:30. Music for zampogna, single ciaramella and ciaramella duo (played respectively by Alberico Larato, Nicola Scaldaferri and Quirino Valvano).

5:50. Voices. Local hunters shoot at the maggio.

\section{Sound-chapters - by Nicola Scaldaferri}

Unless otherwise stated, all recordings are by Nicola Scaldaferri; editing by Nicola Scaldaferri and Lorenzo Pisanello; mastering by Lorenzo Pisanello.

1 The saint and the tree (11.58)

This sound-chapter includes field recordings made in Accettura, mainly during the Maggio festival but also on different occasions. Its aim is to display the variety of sound-making practices that revolve around the tree ritual of the Maggio and people's devotion to St Julian.

0:03. Accettura. 30 May 2004. Evening of Pentecost Sunday. The cima arrives in the village. Its carriers and young people sing and dance, 
while the bassa musica guides and controls their movements through the streets. Excerpt from track 19 in Stella (2005).

1:36. (rec. Cristina Ghirardini). Accettura. 7 May 2005. Pentecost Tuesday. The symphonic march Sivigliana, composed by Adolfo Di Zenzo, is performed by a large symphonic band, the Orchestra di Fiati Raffaele Miglietta, from Corato. The band is accompanying in procession the statue of St Julian in the main street of Accettura. This is the core of the religious ceremonial of the festival. Excerpt from track 6 in CD 2 in Scaldaferri and Feld (2019).

3:51. Woods of Gallipoli-Cognato, near Accettura. 30 May 2004. Pentecost Sunday. A zampogna song performed in the woods, during the cutting of the cima. Alberico Larato accompanies with a small zampogna the singers Domenico Fanuele, Giuliano Moles and Antonio Fanuele, who challenge each other with a satirical take on some romantic lines: 'How beautiful you are, lucky you / lucky the mother who holds you / I got a beating and I will get some more / but I have to keep my pride / How beautiful is it to be close to your love / you can hear her call the chickens / You can hear her call the chickens / my beauty, come and visit me'. Excerpt from track 18 in Stella (2005).

5:42.Accettura. 1 June 2004. Night of Pentecost Tuesday, conclusion of the Maggio festival. The soundscape is dominated by the fireworks; however, the bassa musica keeps fulfilling its role by playing a waltz in the background and interacting with the bangs. Excerpt from track 5 in CD 2 in Scaldaferri and Feld (2019).

7:16. (rec. Giuseppe Filardi). Accettura. 1983. The Lord's Prayer of St Julian, performed by Filomena Bartiluccio, aged eighty-eight. The recording comes from the research archive of the parish priest. From the lyrics: 'The night has come and may God be praised / let us address the Lord's Prayer to St Julian / St Julian of Altomonte / walked across valleys and mountains'. Excerpt from track 1 in CD 2 in Scaldaferri and Feld (2019).

8:13. Accettura. 1 June 2004. Pentecost Tuesday, after the maggio has been raised. Berardino Barbarito accompanies the old singers Vito Piliero and Giuseppe Rocco with his organetto. They challenge each other with a satirical take on some romantic lines: 'Olive leaf fix your braids / because your father wants to give you away / Here comes the one who loves me / with one broken leg and the other in a bad way / Oh young man, break these chains / when I was your age, poor girls'. Excerpt from track 19 in Stella (2005).

10:24. Accettura. 26 January 2020. Eve of St Julian's day. The statue of St Julian is carried in a procession despite the rain, wrapped in plastic sheets. The members of Accettura's symphonic band play some pages from Verdi's Ernani. 


\section{Rhythms in the dark (9:20)}

This sound-chapter is primarily a composition of recordings made on the night of the 2002 Campanaccio in San Mauro Forte. They were all made in the small square in front of the church of St Roch, where the largest sonic convergence happens. All teams of bell carriers must transit by this location at least once during the ritual. They pay homage to the statue of St Anthony the Abbot by circling three times around this church, where the statue is kept. Teams often confront each other in the square, creating sonic jams in which each team tries to keep their own tempo without being diverted by the others.

The teams of bell carriers, each with their own tempo, were recorded separately during their arrival at the church. The recordings are edited so as to highlight the sonic identity of each team and the duels that take place when teams meet. As a coda, almost as a reverberation, the track ends with the soundscape of a valley near the village of San Mauro: cowbells are recorded as they ring from around the neck of hundreds of animals descending from the hills.

0:03. San Mauro Forte. 16 January 2002. Composition of recordings made during the night of the Campanaccio.

7:05. Valley of the river Sauro. 26 January 2020. A bovine herd with cowbells descends along the road, heading from the hills towards the sea.

\section{3 'We came a long way...' (11:40)}

This sound-chapter includes sound events recorded in different moments of the festival of the Madonna del Pollino, as well as at other Marian festivals in Basilicata. Throughout, sound is used to mark an event and take control of space.

0:03. Sanctuary of the Madonna del Pollino, San Severino Lucano. Sunday 2 July 1989. A portion of the sonic duel between two zampogna players, Emilio and Carmine, at the entrance of the sanctuary (see chapter 3). It is the day after the main event of the festival, when the church remains open and the statue receives the homage of the pilgrims who could not join during previous days. At 1:05, when Emilio takes a break, Carmine addresses him: I wish you a thousand years, mate. Stop for a little while, please!' But as Carmine starts to play, Emilio again blows in his louder instrument and forces Carmine to leave the church.

2:44. (rec. Lorenzo Ferrarini). Sanctuary of the Madonna del Pollino. Evening of Friday 4 July 2014. Soundwalk around the area in front 


\section{Listening guide}

of the church, not far from the spot where years before the duel between zampogna players had taken place. The quickly changing soundscape reveals the presence side by side of different groups of pilgrims, each with their musical instruments and styles, as they prepare to go inside the church.

5:20. (rec. L. Ferrarini). Sanctuary of the Madonna della Conserva, San Costantino Albanese. Saturday 20 August 2016. A game of morra on the evening of the festival. The players are involved in a faceto-face challenge made of sounds and gestures; they dominate the surroundings with their shouts and attract people nearby.

6:41. Sanctuary of the Madonna del Pollino. Night of Friday 4 July 2003. Soundscape inside the church, recorded with the microphone in front of the statue of the Madonna. The changes in music reveal a succession of different groups of pilgrims. We hear zampogna music, devotional songs, organetto, tamburello and bottle percussed with a metal key. Excerpt from track 8 in Scaldaferri and Vaja (2006).

8:46. Sanctuary of the Madonna del Pergamo, Gorgoglione. 12 June 2003. Song performed by the piercing voices of the women who carry the statue of the Madonna in the procession. The festival is in its most intense phase and approaches its conclusion. This is the last opportunity to ask the Madonna for divine favour, promising to come back next year:'The Madonna all around / calls her devotees / Calls them all together / give me divine favour my Madonna ... Now I have to go / what will I leave you with? / I leave you with the Ave Maria / take care my Madonna'. Excerpt from track 10 in Stella (2005).

\section{Dancing with wheat $(11: 06)$}

This sound-chapter is entirely composed of field recordings made during wheat festivals in Basilicata. The music of the tarantella creates a common sonic thread that connects all the festivals and invites the participants to dance.

0:03. Piano delle Mandrie, Terranova di Pollino. 5 August 2018. Soundscape of the Palio del Grano reaping competition. The sound of the sickles at work is layered with the amplified voices of the organisers, who provide a live commentary of the unfolding of the competition. In the meantime, zampogna, organetto and tamburello play tarantella music.

2:15. Teana. 9 August 2011. Madonna delle Grazie festival. At the end of the procession, in front of the church and the statue of the Madonna, people dance with wheat offerings on their heads to the sound of a tarantella played by zampogna, organetto and tamburello. 
3:20. Teana. 8 August 2016. Madonna delle Grazie festival. In front of the sanctuary dedicated to the Madonna, just outside the village, people dance with the wheat offerings to a medley of popular songs played by a walking band.

4:31. San Paolo Albanese. 16 August 2005. St Roch festival. Quirino Valvano plays the zampogna for the dance of the sickle, at the head of the procession.

5:41. (rec.Yuval Avital). San Paolo Albanese. 16 August 2010. St Roch festival. Antonio Abitante, Nicola Scaldaferri (ciaramella) and Piero Abitante (zampogna) play for the dance of the sickle performed at the head of the procession.

6:16. Senise. 16 August 2016. St Roch festival. Soundscape of the procession along the village streets: fireworks and tarantella with organetto, zampogna and tamburello, while the participants dance with wheat offerings.

6:54. Noepoli. 6 August 2004. Madonna di Costantinopoli festival. Soundscape at the entrance to the village: walking bands and organetto play a tarantella, while the participants dance with candle and wheat offerings.

7:49. Episcopia. 5 August 2015. Madonna del Piano festival. On the arrival of the procession from the sanctuary at the village square, the participants dance and sing with wheat offerings, to the sound of clapping hands, drums and of a walking band.

9:19. Pedali di Viggianello. 21 August 2004. Evening of the Madonna del Carmine festival. In the village square a folk band performs on an amplified stage, providing music for dancing with wheat offerings: 'Water is bad for you / wine makes you sing / Something in the air of Pedali / always lifts you up'. On the same day tractor engines, church bells, tamburelli and organetti can be heard at the end of the procession.

\section{Memories from a loyal companion (9:55)}

This chapter comprises tape recordings made by Giuseppe Chiaffitella between 1957 and 1962 in San Costantino Albanese and in Brooklyn, New York. It is structured in three sections, each making a different use of the recordings. In the first, soundbites of voices in different languages and instrumental music are edited with a fast pace, using overlaps and cross-fades, following the model of magnetic tape compositions from the 1950s. In the second section, music is a background for speech, which is maintained in the foreground in a similar way to radio programmes. In the third section songs are in the foreground and only partially overlapped with the spoken word. Chiaffitella's voice, 


\section{Listening guide}

speaking and singing in three different languages, acts as a common thread.

\section{I) Sound memories.}

0:03. In English, Chiaffitella introduces a recording session in San Costantino, in order to bring voices to some American relatives. Holiday bells of the main church.

0:36. Voices of friends and relatives in Arbëresh, Italian and English.

1:08. Zampogna music performed by Pietro Laico.

2:06. Music performed by Attilio Cardone (violin), Michele Schillizzi (guitar). A nun's speech thanking the emigrants for the money received to build a kindergarten. A speech about friendship by Antonio Scutari, future mayor of the village. Dhurana's ritual lament for her distant daughter.

2:50. Music performed on accordion by Pasquale Scaldaferri.

3:13. The laughter of Fiorina and Nicodemo's poem, in Brooklyn. Friends in San Costantino record their names.

II) 'Terra straniera'

4:15. Domenico Chiaffitella, Giuseppe's cousin, performs the Italian song Terra straniera (foreign country), made famous in the 1950s by singers Claudio Villa and Luciano Tajoli. At the time, the song was an anthem for the emigrants. Layered with the voice of Giuseppe Chiaffitella and with that of Agostino Canosa, who introduces a recording session with voices and songs addressed to Giuseppe from his friends 'to take as souvenirs across the ocean and to listen to in moments of sadness and nostalgia'.

\section{III) Homeland as song}

$6: 38$. The song of the vallja ('that will forever remain in the history of the village', see chapter 5) performed on Easter Monday by the women of the village, layered with the voice of Chiaffitella introducing it in Arbëresh.

7:20. Male voices perform a love song accompanied by Vincenzo Carbone (accordion), Nicola Trupo (percussion) and Michelino D'Amato (guitar): 'Oh dark carnation I would like to kiss your mouth / Oh scarlet carnation I would like to kiss you all night'.

8:10. Chiaffitella and other male voices perform the religious song Christos Anesti, in Greek, announcing Christ's resurrection in the early morning of Easter.

9:03. A song of love and nostalgia composed and sung in the USA by Chiaffitella, remembering the faraway village: 'Tonight the stars are shining / like that time when I was in love / a love that flew 
away / and left me only a memory / When I pass by those places / and remember those kisses / my eyes fill with tears / and my heart sighs'.

\section{A musical journey with my zampogna (10:14)}

The chapter includes recordings from separate moments of Scaldaferri's activity with the zampogna in Basilicata, some in the frame of academic research and others as part of artistic practice.

0:03. (rec. Francesco Giannattasio). San Paolo Albanese. 13 May 1990. During team research led by ethnomusicologist Francesco Giannattasio, Scaldaferri plays a 3.5 palm zampogna to accompany the voices of Caterina Osnato, Domenica Caluori and Andreana Buccolo. The women singers 'respond' to the instrument with a piercing and almost shouted song, which includes typical lines of greeting: 'Oh what a day this is / I could sing until tomorrow / I only regret having turned old'. Excerpt from track 26 in Scaldaferri (1994).

2:07. (rec. Elisa Piria). Stigliano. 29 August 2002. Scaldaferri uses an old zampogna of 4.5 palms made by Carmine Trimarco and recorded during the research of De Martino in the 1950s. Fifty years later, in the same area, he 'provokes' the singer Leonardo Ripullone to remember a love song: 'I went up and I came down / I found my beauty drying clothes / Peppe plays and Caterina sings / so they say they are happy'. Excerpt from track 6 in Stella (2005).

3:37. (rec. and mastering Gerardo Greco). Trëndafile baxhanare (The Vain Rose). Lyrics by Enza Scutari and music by Nicola Scaldaferri, sung by Quirino Valvano, Pina Ciminelli, Dina Iannibelli, Pina Magnocavallo and Alexandra Nikolskaya. Lyrics: 'A rose so vain / stood alone in a meadow / Along came some flowers and told her / 'Come with us, oh vain / if you come with us / you will become even more beautiful!' / 'I can't come with you...'. The song is based on a traditional tarantella rhythm, played by Scaldaferri with two overdubbed zampogne ( 3 and 6 palms), and accompanied by other instruments (tamburello, violin, mandolin, accordion, piano), plus male and female singers in a traditional Arbëresh style. Scutari's poem tells the story of the vain rose, who disdains the company of other flowers. The song is part of the project Lule sheshi, devoted to the poet Enza Scutari. Excerpt from track 12 in Nikolskaya and Scaldaferri (2010).

6:38. Matera. 1 September 2019. A portion of URLA, an itinerant crowd music composition by Yuval Avital, part of the initiatives for the European Capital of Culture. The more than three hundred 
performers, from the most representative sound traditions in Basilicata, were divided into four itinerant groups. One of them was made up of fifteen zampogne ranging from small 2 palm instruments to giant-sized 8 palm ones (over $2 \mathrm{~m}$ long). Following the directions of the composer, the instruments performed sonic textures, crossing along their path the sound of other performers placed in the streets. The group of zampogne was led by Scaldaferri, who played a small zampogna and at the same time recorded with a microphone fixed on his back. 